\title{
Candida bracarensis: Evaluation of Virulence Factors and its Tolerance to Amphotericin B and Fluconazole
}

\author{
André Moreira $\cdot$ Sónia Silva $\cdot$ Cláudia Botelho $\cdot$ \\ Paula Sampaio • Célia Pais · Mariana Henriques
}

Received: 1 February 2015 / Accepted: 6 July 2015/Published online: 16 July 2015

(C) Springer Science+Business Media Dordrecht 2015

\begin{abstract}
Candida bracarensis is an uncommon Candida species found during an epidemiological study of candidiasis performed in Braga, Portugal. Initially, it was identified as $C$. glabrata, but recently detailed analyses pointed out their differences. So, little information is still available about $C$. bracarensis virulence factors and antifungal susceptibilities. Therefore, the main goal of this work is to evaluate the ability of $C$. bracarensis to form biofilms, to produce hydrolytic enzymes (proteases, phospholipases and hemolysins), as well as its susceptibility to amphotericin B and fluconazole. It was shown, for the first time, that all C. bracarensis strains were able to form biofilms and display proteinase and hemolytic activities. Moreover, although planktonic cells presented antifungal susceptibility, amphotericin B and fluconazole were unable to inhibit biofilm formation and eradicate pre-formed biofilms. Due to the propensity of $C$. bracarensis to display antifungal resistance
\end{abstract}

A. Moreira · S. Silva $(\bowtie) \cdot$ C. Botelho $\cdot$ M. Henriques CEB, Centre of Biological Engineering, LIBRO Laboratório de investigação em Biofilmes Rosário Oliveira, University of Minho, Campus de Gualtar, 4710-057 Braga, Portugal

e-mail: soniasilva@deb.uminho.pt

P. Sampaio - C. Pais

CBMA, Centre of Molecular and Environmental Biology, Department of Biology, University of Minho, Campus de Gualtar, 4710-057 Braga, Portugal and virulence attributes, the control of these emerging pathogens is recommended.

Keywords Candida bracarensis · Virulence factors · Antifungal resistance $\cdot$ Amphotericin B · Fluconazole

\section{Introduction}

Among the several Candida species that cause human infections, Candida albicans is recognized as the most frequent and pathogenic [1,2]. Nevertheless, some authors [3, 4] have reported that there are other important pathogenic members in the Candida group, namely Candida tropicalis, Candida glabrata and Candida parapsilosis [5]. With the advances in the polymerase chain reaction (PCR)-based techniques, previously unrecognized "cryptic" species have been identified and added to the list of human pathogens [6]. Recently, Candida bracarensis was identified as a new Candida species under an epidemiological study of candidiasis performed in Braga, Portugal [7]. Initially, it was phenotypically confused with $C$. glabrata, but later some studies showed differences between them and justified the description of a new species [6, 7].

Candida species present several virulence factors, such as ability to adhere to host tissues or medical devices, biofilm formation, hydrolytic enzymes production (e.g., proteases, phospholipases and hemolysins) 
and ability to filament [6]. Biofilm formation, which includes cells adhered to a surface and embedded in an extracellular matrix, is dependent on the strain, substrate properties and growth conditions [8]. Hydrolytic enzymes are causative agents of host destruction, while the filamentous structures have a relevant role in the invasion of pathogen in the host tissue [5].

The high prevalence of Candida species in infections, namely in a biofilm lifestyle, is also a reflection of their inherent high level of resistance to certain antifungal drugs [5]. Moreover, this resistance started to increase among Candida species in consequence of the rise of invasive fungal infections caused by the same microorganisms [9]. With this argument of infections, antifungal agents are being used excessively, thus contributing to the increase in resistant species and the occurrence of mutations related to resistance [10]. Besides being a problem for human health, antifungal resistance also causes big economic problems [11].

The true clinical relevance of the possible misidentification of $C$. bracarensis as $C$. glabrata is under evaluation, since this species is relatively rare [12]. However, in vitro susceptibility studies of $C$. bracarensis isolates were comparable to those found with $C$. glabrata $[6,12]$. Thus, it is important to study this emerging human pathogen. To author's best knowledge, to date, there are no in vitro studies for the determination of $C$. bracarensis virulence factors and only few concerning its antifungal resistance [6, 12]. Therefore, the main aim of this work is to assess the in vitro expression of potential virulence factors of C. bracarensis strains and to determine the effect of amphotericin B and fluconazole against planktonic cells and on the formation and control of biofilms.

\section{Materials and Methods}

\section{Organisms}

Three $C$. bracarensis isolates were used in this study: (i) NCYC 3133, isolated from a central venous catheter in the United Kingdom; (ii) CNM-CL-7030, isolated from a catheter exudate and belonging to the Spanish National Centre for Microbiology Yeast Collection; and (iii) $153 \mathrm{M}^{\mathrm{T}}$, obtained from a vaginal sample of a patient with candidiasis, at the Hospital of
São Marcos (Braga, Portugal). These strains were identified by sequencing of the D1/D2 domain of the 26S rDNA and ITS1/ITS2 regions [7]. Additionally, two reference strains of C. albicans (ATCC 90028)the Candida species more studied at all levels-and $C$. glabrata (ATCC 2001) - the species that presents more phenotypic similarities with $C$. bracarensisfrom the American Type Culture Collection (ATCC), were also used $[5,7]$.

\section{Biofilm Formation and Extracellular Matrix Composition}

Strains were subcultured on yeast peptone dextrose (YPD) agar medium, which was composed by $1 \%$ (w/ v) yeast extract, $2 \%(\mathrm{w} / \mathrm{v})$ peptone, $2 \%(\mathrm{w} / \mathrm{v})$ glucose and $2 \%(\mathrm{w} / \mathrm{v})$ agar, for $24 \mathrm{~h}$ at $37{ }^{\circ} \mathrm{C}$. Then, yeasts were cultured on YPD broth for $18 \mathrm{~h}$ at $37^{\circ} \mathrm{C}$ under agitation at $120 \mathrm{rpm}$. After incubation, cells were harvested and washed twice (with phosphate-buffered saline [PBS; pH 7.5, 0.1 M]) by centrifugation (at $3000 \mathrm{~g}$ for $10 \mathrm{~min}$ at $4{ }^{\circ} \mathrm{C}$ ). Afterward, cells were enumerated using a Neubauer counting chamber and adjusted to a concentration of $1.0 \times 10^{7}$ cells $/ \mathrm{ml}$ in RPMI 1640 (Sigma, Saint Louis, Missouri, USA) media. Then, biofilms were formed in 96-well polystyrene microtiter plates (Orange Scientific, Braine-l' Alleud, Belgium). A volume of $200 \mu \mathrm{l}$ of the standardized cell suspensions $\left(1.0 \times 10^{7}\right.$ cells $/ \mathrm{ml}$ in RPMI 1640) was added to each well. The plates were incubated at $37{ }^{\circ} \mathrm{C}$ in an orbital shaker at $120 \mathrm{rpm}$ for $24 \mathrm{~h}$. At the end of the respective time, the medium was removed and all wells were washed once with PBS ( $\mathrm{pH}$ $7.5,0.1 \mathrm{M}$ ) to remove the non-adherent cells.

Biofilms were firstly analyzed in terms of the number of colony forming units (CFUs). For that, $200 \mu \mathrm{l}$ of PBS was added to each well and then biofilms were removed from the surface by scrapping [13]. Complete removal of the biofilm was confirmed by subsequent crystal violet (CV) staining [14]. The biofilm suspensions were then vortexed for $5 \mathrm{~min}$ (to disrupt the biofilm matrix), and later, serial decimal dilutions (in PBS) were plated onto YPD agar and incubated for $24 \mathrm{~h}$ at $37{ }^{\circ} \mathrm{C}$. The results were then expressed as the number of CFUs ( $\log _{10} \mathrm{CFUs}$ ).

Biofilms were also analyzed in terms of total biomass quantification by CV staining [14]. For that, after washing it, $200 \mu \mathrm{l}$ of methanol $(100 \% \mathrm{v} / \mathrm{v})$ were 
added to each well, to fix the cells. Methanol was removed after $15 \mathrm{~min}$ of contact and the microtiter plates dried at room temperature. Afterward, $200 \mu \mathrm{l}$ of CV (1\% v/v) were added to each well, which remained in contact with the cells for $5 \mathrm{~min}$. Then, $\mathrm{CV}$ was aspirated, the wells were washed twice with ultra-pure water and $200 \mu \mathrm{l}$ of acetic acid (33\% v/v) were added to dissolve the stain. Lastly, absorbance of CV solutions was read in a microtiter plate reader (Bio-Tek Synergy HT, Izasa, Lisbon, Portugal) at $570 \mathrm{~nm}\left(\mathrm{Abs}_{570 \mathrm{~nm}}\right)$.

In order to analyze the composition of the extracellular biofilm matrix (ECM) which requires the production of higher amounts of biofilms, 24-well polystyrene microtiter plates (Orange Scientific, Braine-l' Alleud, Belgium) were used, in which $1 \mathrm{ml}$ of standardized yeast suspensions $\left(1.0 \times 10^{7}\right.$ cells $/ \mathrm{ml}$ in RPMI 1640) were placed. Microtiter plates were incubated for $24 \mathrm{~h}$ at $37{ }^{\circ} \mathrm{C}$ and $120 \mathrm{rpm}$. After biofilm formation, the culture medium was removed, wells were washed once with PBS (pH 7.5, 0.1 M) and cells were scraped from wells. The biofilms were then resuspended in PBS to a final volume of $5 \mathrm{ml}$. To determine the dry weight of each sample, $1 \mathrm{ml}$ of the suspension was vortexed for $30 \mathrm{~s}$, filtered through a $0.45 \mu \mathrm{m}$ nitrocellulose filter and left to dry at $80{ }^{\circ} \mathrm{C}$ for $24 \mathrm{~h}$. The remaining $4 \mathrm{ml}$ of suspensions was sonicated (Ultrasonic Processor, Cole-Parmer, Illinois, USA), for $30 \mathrm{~s}$ at $30 \mathrm{~W}$, and centrifuged at $5000 \mathrm{rpm}$ for $5 \mathrm{~min}$ at $4{ }^{\circ} \mathrm{C}$, in order to recover the matrix. The supernatant was filtered (through a $0.45 \mu \mathrm{m}$ filter) and stored at $-20{ }^{\circ} \mathrm{C}$ until they were used to protein and carbohydrate quantification. The content of protein present in the extracellular biofilm matrix was determined by the BCA Kit (Bicinchoninic Acid, Sigma-Aldrich, St Louis, USA), using Bovine Serum Albumin (BSA) as standard. The total carbohydrates present in the biofilm matrix were determined according to the procedure described by Dubois et al. [15], using glucose as standard. The carbohydrate and protein contents were normalized by biofilm dry weight. These assays were performed at least three times for each strain and medium.

\section{Enzymatic Activity}

In order to determine the protease activity, fresh cultured colonies were placed onto protease agar medium containing $2 \%(\mathrm{w} / \mathrm{v})$ agar, $1.2 \%(\mathrm{w} / \mathrm{v})$ yeast carbon base, $0.01 \%(\mathrm{w} / \mathrm{v})$ yeast extract and $0.2 \%(\mathrm{w} /$ v) BSA with pH 5.0, according to Rüchel et al. [16]. Afterward, the plates were incubated at $37{ }^{\circ} \mathrm{C}$ for 4 days. After incubation, each plate of protease agar medium was placed in contact with $15 \mathrm{ml}$ of dye solution $(0.1 \%(\mathrm{w} / \mathrm{v})$ amido black, $30 \% \quad(\mathrm{v} / \mathrm{v})$ methanol, $10 \%$ (v/v) acetic acid and $60 \%$ ultra-pure water) for $1 \mathrm{~h}$. Then the plates were washed twice with acetic acid (33\% v/v) and dried at room temperature. Phospholipase activity was determined according to Price et al. [17]. For that, colonies were cultured onto phospholipase agar medium composed by $2 \%$ (w/v) agar, $1 \%(\mathrm{w} / \mathrm{v})$ peptone, $2 \%(\mathrm{w} / \mathrm{v})$ glucose, $1 \mathrm{M}$ $\mathrm{NaCl}, 5 \mathrm{mM} \mathrm{CaCl}_{2}$ and $8 \%$ (w/v) egg yolk, followed by incubation at $37{ }^{\circ} \mathrm{C}$ for a period of 3 days.

The determination of the enzymatic activity was performed by observation of the presence or absence of an opaque inhibition halo around the colonies in both agar media. The enzymatic activity was assessed by the ratio between the colony diameter and the halo plus the colony diameter- $\mathrm{Pz}$ value-according to Price et al. [17]. These assays were performed in triplicate, and C. tropicalis ATCC 750 was used as a positive control and $C$. glabrata ATCC 2001 as a negative control, in the proteolytic activity analysis [18]. Candida albicans ATCC 90028 was used as a positive control and C. glabrata ATCC 2001 as a negative control concerning phospholipase activity determination [19].

Hemolytic activity was evaluated using a modification of the plate assay described by Luo et al. [20]. Fresh cultured colonies were placed inside of sugar-enriched sheep blood medium, with $2 \%(\mathrm{w} / \mathrm{v})$ peptone, $1 \%$ (w/ v) agar, $7 \%$ fresh sheep blood, $3 \%(\mathrm{w} / \mathrm{v})$ glucose. The plates were incubated at $37{ }^{\circ} \mathrm{C}$ for 3 days, and later the hemolytic activity was classified as absent (without halo), partial or total (transparent halo). This experiment was performed in triplicate and $C$. tropicalis ATCC 750 used as a positive control [18].

\section{Planktonic Cells Antifungal Susceptibility Tests}

The reference method described by the Clinical and Laboratory Standards Institute (CLSI) for broth dilution antifungal susceptibility testing of yeast (M27A2) was used to determine the minimum inhibitory concentration (MIC). 
As described in the CLSI M27-A2 standard, MICs were interpreted as follows: (i) amphotericin B: MIC $>1 \mu \mathrm{g} / \mathrm{ml}$-it is probably resistant $(R)$; (ii) fluconazole: $\quad \mathrm{MIC} \leq 8 \mu \mathrm{g} / \mathrm{ml}$-susceptible $\quad(S)$; $16<$ MIC $<32 \mu \mathrm{g} / \mathrm{ml}$-susceptible-dose-dependent $(S D D)$ and $\mathrm{MIC} \geq 64 \mu \mathrm{g} / \mathrm{ml}$-resistant $(R)$. These were repeated in at least three independent assays, being individual samples analyzed in triplicate.

Antifungal Agents Effect on Formation and Preformed Biofilms

In order to assess the effect of antifungal agents on biofilm formation and pre-formed biofilms, fluconazole (at 50, 312.5 and $625 \mu \mathrm{g} / \mathrm{ml}$ ) and amphotericin B (at $0.5,1$ and $2 \mu \mathrm{g} / \mathrm{ml}$ ) prepared in RPMI medium were added at the beginning of the biofilm formation and after $24 \mathrm{~h}$ of growth (pre-formed biofilms).

Then, in the first approach, 96-well polystyrene plates (Orange Scientific) were used and each well was filled with $100 \mu \mathrm{l}$ of antifungal and $100 \mu \mathrm{l}$ of the standardized cell suspensions $\left(2.0 \times 10^{7}\right.$ cells $/ \mathrm{ml}$ in RPMI 1640). The plates were incubated at $37{ }^{\circ} \mathrm{C}$ and $120 \mathrm{rpm}$ for $24 \mathrm{~h}$. In relation to the pre-formed biofilms, $100 \mu \mathrm{l}$ of RPMI 1640 medium and $100 \mu \mathrm{l}$ of the cell suspensions were added to the selected wells, which were incubated at $37{ }^{\circ} \mathrm{C}$ in an shaker (at $120 \mathrm{rpm}$ ). After 24 h, $200 \mu \mathrm{l}$ of culture medium was removed and an equal volume of the respective antifungal concentration was added to the plates that were incubated for further $24 \mathrm{~h}$. After each incubation time, the culture medium was aspirated and the wells were washed once with PBS ( $\mathrm{pH} 7.5,0.1 \mathrm{M})$. The results were assessed using CFUs enumeration and by the total biomass quantification (through CV staining). The results were presented as absorbance values $\left(\mathrm{Abs}_{570} \mathrm{~nm}\right)$ and $\log _{10}$ CFUs. Experiments were performed in triplicate and in four independent assays.

\section{Statistical Analysis of Data}

Statistical analysis was performed using GraphPad Software (San Diego, CA, USA). The two-way ANOVA with the Bonferroni post hoc test was used to determine statistical differences between the several strains studied. The same procedure was also used to compare the controls $(0 \mu \mathrm{g} / \mathrm{ml})$ with the resistance of strains to different concentrations of antifungal agent. All tests were performed with a $95 \%$ confidence level.

\section{Results}

Candida bracarensis Strains are Able to form Biofilm

Biofilm formation ability by $C$. bracarensis was performed in RPMI 1640 during $24 \mathrm{~h}$ and quantified by CFUs enumeration (Fig. 1a) and total biomass determination (Fig. 1b). It was evident that all $C$. bracarensis strains were able to form biofilm, but with some specific differences concerning the strains. In terms of the number of viable cells (Fig. 1a), no statistical differences were observed among the three C. bracarensis strains' biofilms $(p>0.05)$, even comparatively to $C$. albicans and $C$. glabrata strains $(p>0.05)$. Contrarily, concerning the total biomass quantification, significant differences were detected between the $C$. bracarensis strains ( $p<0.05$ ), with $C$. bracarensis $153 \mathrm{M}^{\mathrm{T}}$ presenting the highest value followed by the strains CNM-CL-7030 and NCYC 3133 .

In order to better characterize $C$. bracarensis biofilms, protein and carbohydrates content, extracted from biofilm matrices, was also assessed (Table 1). The results showed that likewise, in $C$. albicans and $C$. glabrata species, proteins and carbohydrates are matrices constituents of the $C$. bracarensis biofilm. Concerning the protein content, results showed no statistically significant differences $(p>0.05)$ between the protein levels extracted from matrices of the different strains, even comparatively to $C$. albicans and C. glabrata matrices $(p>0.05)$. In relation to the carbohydrate quantification, no statistical differences were found between the $C$. bracarensis strains tested $(p>0.05)$; however, it was verified that biofilm matrix of the C. glabrata had significantly higher quantity of carbohydrate than the other biofilm matrices ( $p<0.001$ vs. C. albicans and C. bracarensis).

Candida bracarensis Present Proteolytic and Hemolytic Activity

Enzymes' production is described as an important Candida virulent factor; thus, the proteolytic, phospholipidic and hemolytic activities of $C$. bracarensis strains were accessed. After incubation of fresh $C$. bracarensis colonies onto agar medium supplemented with BSA, it was possible to conclude that from the 


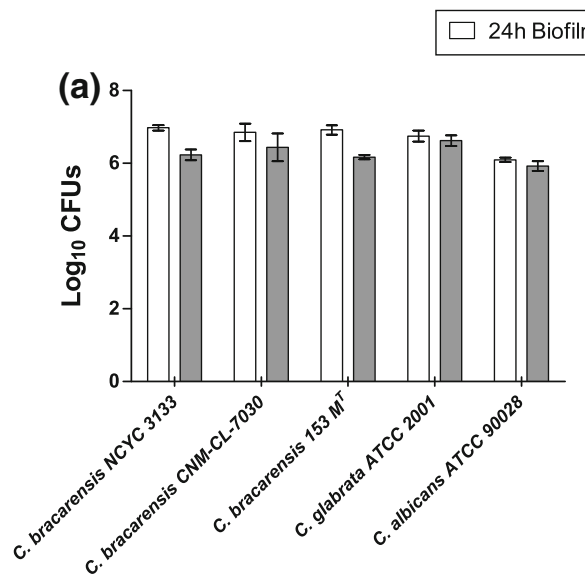

Fig. 1 Candida bracarensis biofilm formation. (a) Number of viable cells ( $\log _{10}$ CFUs) and (b) absorbance values ( $\mathrm{Abs}_{570 \mathrm{~nm}}$ ) of crystal violet solutions of biofilm formed in RPMI during $24 \mathrm{~h}$ by Candida species. Error bars represent standard

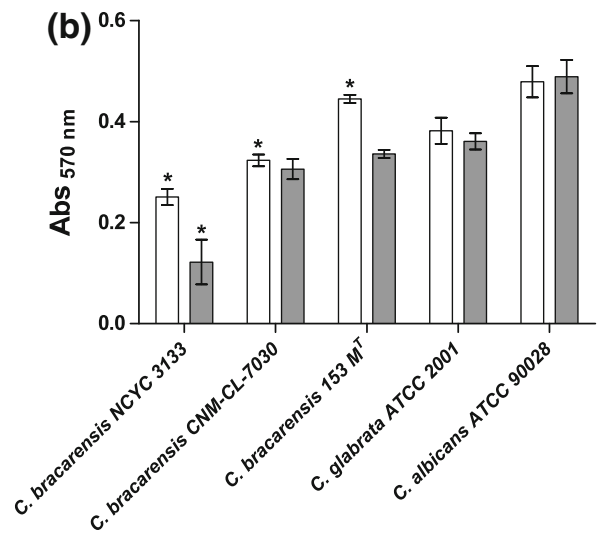

deviation, as result of three assays performed for each strain and medium. *Statistical difference compared to biofilms formed by other strains of the C. bracarensis species $(p<0.05)$

Table 1 Protein and carbohydrate contents (mg/g of biofilm dry weight) extracted from biofilms matrices formed in RPMI during 24 h by different Candida strains. The values are means \pm standard deviations

\begin{tabular}{lcc}
\hline Species & \multicolumn{2}{l}{ Biofilm matrix composition (mg/g of biofilm dry weight) } \\
\cline { 2 - 3 } & \multicolumn{1}{l}{ Proteins } & Carbohydrates \\
\hline C. bracarensis NCYC 3133 & $5.08 \pm 0.29$ & $58.07 \pm 32.82$ \\
C. bracarensis CNM-CL-7030 & $12.98 \pm 6.46$ & $34.47 \pm 10.34$ \\
C. bracarensis $153 \mathrm{M}^{\mathrm{T}}$ & $1.70 \pm 1.10$ & $45.17 \pm 21.98$ \\
C. glabrata ATCC 2001 & $7.57 \pm 1.25$ & $157.38 \pm 40.48 * * *$ \\
C. albicans ATCC 90028 & $10.22 \pm 1.96$ & $38.15 \pm 15.96$ \\
\hline
\end{tabular}

Statistical difference compared to biofilm matrix formed by other Candida species $(* * * p<0.001)$

three strains used, only C. bracarensis (NCYC 3133) presented proteolytic activity $(\mathrm{Pz}=0.44)$, likewise $C$. tropicalis $(\mathrm{Pz}=0.44)$ and $C$. albicans $(\mathrm{Pz}=0.47)$. Moreover, C. bracarensis strains were not able to produce phospholipases $(\mathrm{Pz}=1.00)$, like $C$. glabrata $(\mathrm{Pz}=1.00)$ and in opposition to $C$. albicans $(\mathrm{Pz}=0.38)$. Nevertheless, all $C$. bracarensis strains tested were able to express total hemolytic activity on sugar-enriched sheep blood medium.

\section{Candida bracarensis Planktonic Cells Response to Antifungal Agents is Variable}

The levels of Candida strains susceptibility to amphotericin B and fluconazole, in the planktonic lifestyle, are presented in Table 2 .
Concerning amphotericin B, it was verified that, in opposition to all other strains, C. bracarensis NCYC 3133 presented a more resistant profile (MIC $>1 \mu \mathrm{g}$ / $\mathrm{ml})$. In the case of fluconazole, it was possible to infer that all $C$. bracarensis strains are susceptible-dosedependent, in opposition to C. albicans ATCC 90028 and C. glabrata ATCC 2001, which are resistant to this agent.

\section{Candida bracarensis Biofilm Formation is Reduced by Antifungal Agents}

To infer about the effect of amphotericin B and fluconazole in $C$. bracarensis biofilm formation, biofilms were formed in the absence and presence of both antifungal agents. The results, presented as 
Table 2 In vitro susceptibility of Candida strains for amphotericin B and fluconazole

$R$ resistant, $S$ susceptible; $S D D$ susceptible-dosedependent
Species

Susceptibility category (MIC $\mu \mathrm{g} / \mathrm{ml}$ )

Amphotericin B

Fluconazole

C. bracarensis NCYC 3133

$S(>1)$

SDD (16-32)

C. bracarensis CNM-CL-7030

$S(0.5-1)$

SDD (16-32)

C. bracarensis $153 \mathrm{M}^{\mathrm{T}}$

$S(0.25-0.5)$

SDD (16-32)

C. glabrata ATCC 2001

$S(0.5-1)$

$R(\geq 64)$

C. albicans ATCC 90028
$S(0.5-1)$
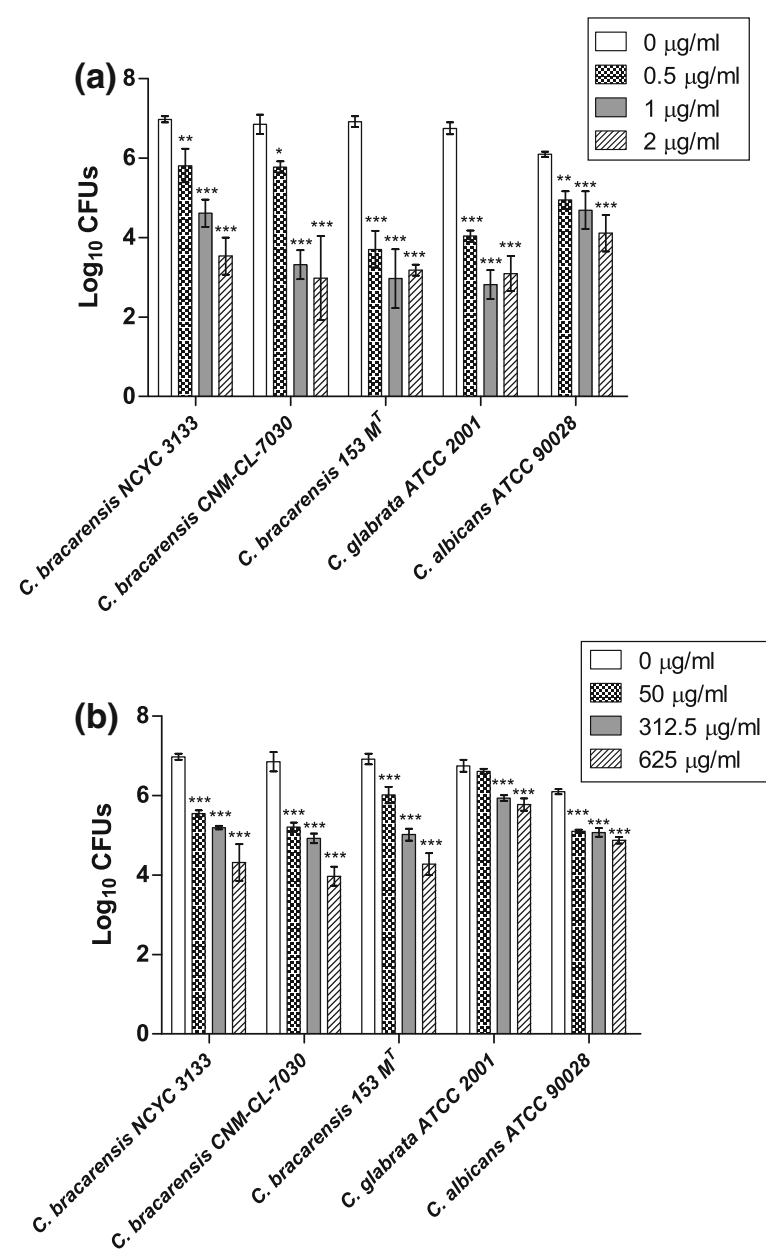

Fig. 2 Amphotericin B and fluconazole effect against biofilm formation of $C$. bracarensis. (a, b) Number of viable cells ( $\log _{10}$ CFUs) of Candida species and (c, d) absorbance values $\left(\mathrm{Abs}_{570 \mathrm{~nm}}\right)$ of $\mathrm{CV}$ solutions of biofilm formed in the presence of (a, c) amphotericin B and (b, d) fluconazole. Error bars

the number of viable cells (Fig. 2a, b) and the total biomass values (Fig. 2c, d), highlight the incapacity of the fungicide (amphotericin B) and fungistatic (fluconazole) agents to totally inhibit biofilm
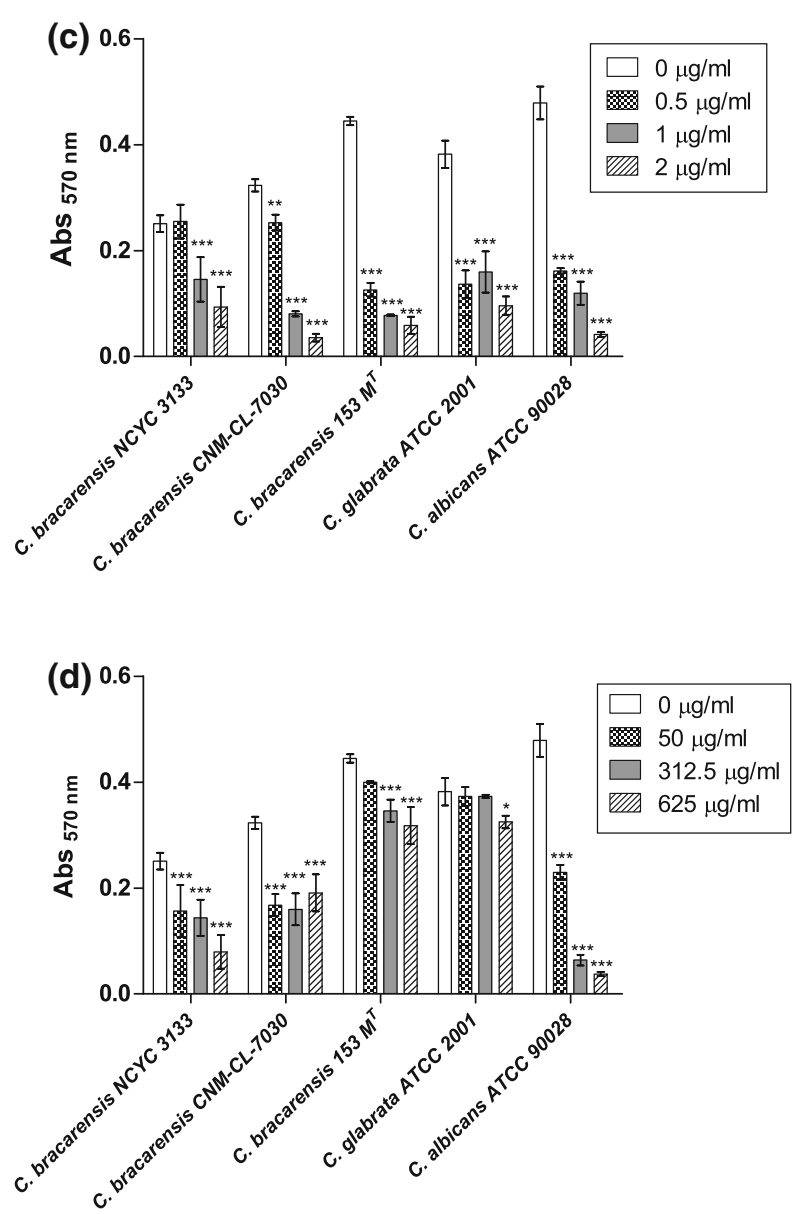

represent standard deviation, as result of four independent assays, where each condition was analyzed in triplicate. Statistical difference compared to respective control $(* p<0.05 ; * * p<0.01 ; * * * p<0.001)$

formation, within the range of concentrations tested.

Regarding amphotericin $\mathrm{B}$, all tested concentrations caused some reduction $(p<0.05)$ in the 
number of viable cells (Fig. 2a) and biofilm biomass (Fig. 2c). It is important to address that this effect increased with the amount of antifungal tested. In addition, it was also verified that $C$. glabrata and $C$. bracarensis $153 \mathrm{M}^{\mathrm{T}}$ biofilms presented the highest reduction in terms of the number of viable cells and biofilm biomass. On the other hand, $C$. bracarensis NCYC 3133 biofilm had the lowest reduction in the biomass.

In what concerns fluconazole (Fig. 2b, d), it can be seen that this antifungal agent significantly inhibited the biofilm formation of all species $(p<0.05)$, but with lower extension in the case of $C$. glabrata. In Fig. $2 b$ it is possible to observe that fluconazole affected biofilm formation in a similar way for the three C. bracarensis strains. During C. bracarensis biofilms' formation, the inhibition imposed by different fluconazole concentrations in the viable cells' number was higher than in C. glabrata and C. albicans biofilms. Contrarily, and according to values from Fig. 2d, the total biomass reduction in the $C$. bracarensis biofilm was lower than in the $C$. albicans biofilm, but remained higher than in the $C$. glabrata biofilms. In addition, among $C$. bracarensis species, the lowest biomass reduction happened in the biofilm of strain $153 \mathrm{M}^{\mathrm{T}}(<28.5 \%)$, regardless of the tested fluconazole concentration.

Pre-formed Biofilms of Candida bracarensis are Low Affected by Antifungal Agents

To evaluate the effect of amphotericin B and fluconazole on pre-formed biofilms of $C$. bracarensis, 24 preformed biofilms were treated with amphotericin B and fluconazole and its effect was evaluated after additional $24 \mathrm{~h}$ (Fig. 3). The number of viable cells (Fig. 3a, b) and the total biomass values (Fig. 3c, d) obtained showed that the antifungal agents' effect was effectively lower comparatively to the effect observed during biofilm formation (Fig. 2), however, with some specific differences concerning the strains and antifungal agent test.

In relation to amphotericin $\mathrm{B}$, all concentrations tested were unable to reduce pre-formed $C$. bracarensis NCYC 3133 biofilm $(p>0.05)$, either in terms of the number of viable cells (Fig. 3a) or in terms of total biomass (Fig. 3c). In relation to the other strains, it was verified that $0.5 \mu \mathrm{g} / \mathrm{ml}$ of amphotericin $\mathrm{B}$ had a statistically significant positive effect in the reduction in the number of viable cells of $C$. bracarensis $153 \mathrm{M}^{\mathrm{T}}$ $(p<0.001)$ and $C$. albicans ATCC $90028(p<0.01)$. However, the total biomass values revealed only a significantly positive effect $(p<0.01)$ in the biofilm of these species for values of concentrations higher than $1 \mu \mathrm{g} / \mathrm{ml}$. Moreover, in the case of $C$. glabrata and $C$. bracarensis CNM-CL-7030 biofilms, a significant reduction $(p<0.05)$ in the number of viable cells was observed, despite only for concentrations of 1 and $2 \mu \mathrm{g} / \mathrm{ml}$, whereas the biomass of these biofilms suffered a statistically significant decrease with $0.5 \mu \mathrm{g} / \mathrm{ml}$ $(p<0.05)$ and $2 \mu \mathrm{g} / \mathrm{ml}(p<0.001)$, respectively.

In the case of fluconazole, this antifungal agent had no effect on the number of viable $C$. bracarensis NCYC 3133 biofilm's cells ( $p>0.05$ ), comparatively to control (Fig. 3b). Nevertheless, in Fig. 3d, it is possible to observe that the total biomass increased significantly in the presence of $625 \mu \mathrm{g} / \mathrm{ml}$ of fluconazole comparatively to the control $(p<0.01)$. The same happened for $C$. glabrata biofilm, regarding the biomass values. Figure $3 \mathrm{~b}$ also shows that the number of viable cells of $C$. albicans and C. bracarensis 153 $\mathrm{M}^{\mathrm{T}}$ biofilms statistically decreased, however, only for higher concentrations of fluconazole $(625 \mu \mathrm{g} / \mathrm{ml})$. In contrast, and concerning total biomass values (Fig. 3d), it was observed that both strains presented opposite behaviors in relation to the fluconazole action. Furthermore, fluconazole, at the same concentration $(50 \mu \mathrm{g} / \mathrm{ml})$, was able to reduce the number of C. bracarensis CNM-CL-7030 biofilms $(p<0.01)$ and its total biomass amount $(p<0.05)$ comparatively to the control.

\section{Discussion}

Candida bracarensis is a commensal human fungus and, comparatively to $C$. albicans and to other Candida species, relatively few investigations have been carried out to assess its virulence factors and its susceptibility to traditional antifungal agents [6, 7]. Moreover, initially, C. bracarensis was misclassified as $C$. glabrata upon its discovery, and the results presented here highlight these differences, not only concerning species but even strains $[4,7]$.

Biofilm formation is an important phenomena that contributes for the survival and colonization of Candida species in host tissues and medical devices [21]. In the present study, it was observed for the first 


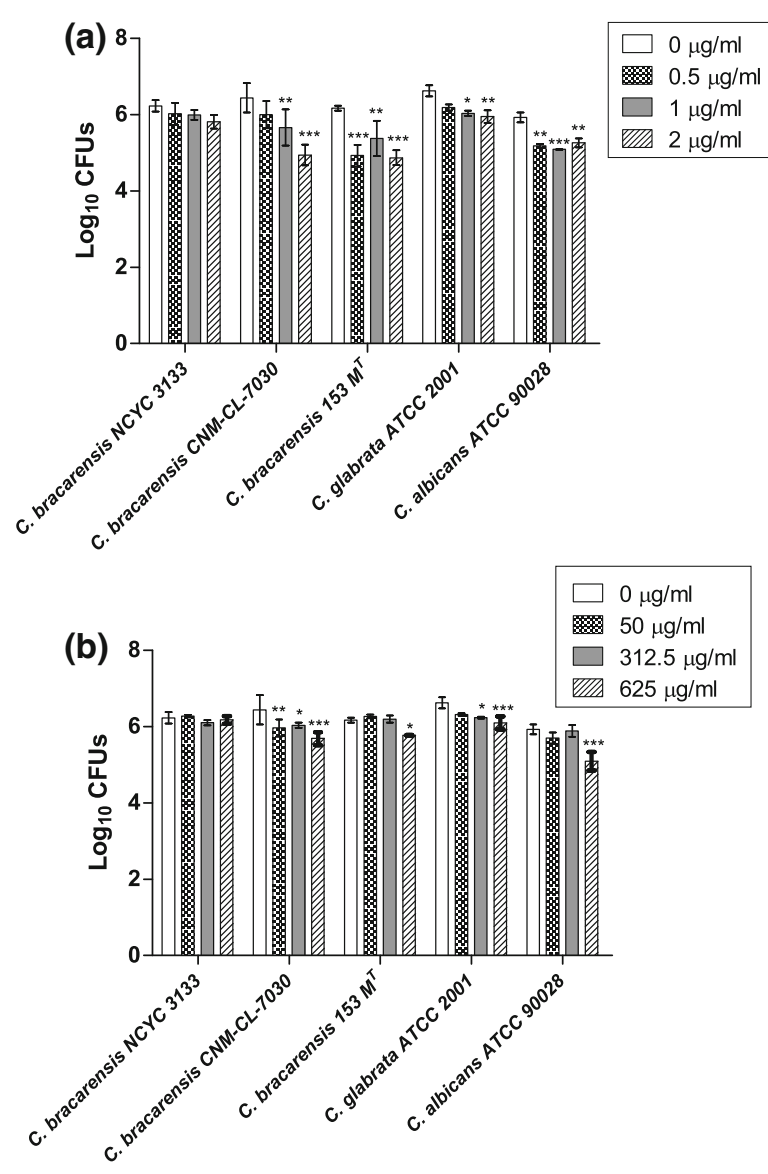

Fig. 3 Amphotericin $\mathrm{B}$ and fluconazole effect against $C$. bracarensis $24 \mathrm{~h}$ pre-formed biofilm. a, b Number of viable cells ( $\log _{10}$ CFUs) of Candida species and $\mathbf{c}$, $\mathbf{d}$ absorbance values $\left(\mathrm{Abs}_{570 \mathrm{~nm}}\right)$ of $\mathrm{CV}$ solutions of biofilm treated with (a, c) amphotericin B and $(\mathbf{b}, \mathbf{d})$ fluconazole. Error bars represent

time that $C$. bracarensis strains were able to form biofilms, although in different extents depending on the strains (Fig. 1), likewise other Candida species (such as C. albicans and C. glabrata) [21].

One of the most important characteristics of fungal biofilms is the presence and the composition of the ECM [8, 22]. Biofilm matrix is composed by several products secreted by microbial cells and acts as a barrier to the diffusion of antimicrobial agents, preventing, for that reason, the penetration and the access of drugs to cells located at the base of the biofilm $[8,23]$. This study highlights, for the first time, that $C$. bracarensis biofilm matrices are constituted by proteins and carbohydrates, likewise $C$. albicans and C. glabrata biofilms (Table 1). Nevertheless, significant differences were also observed concerning the
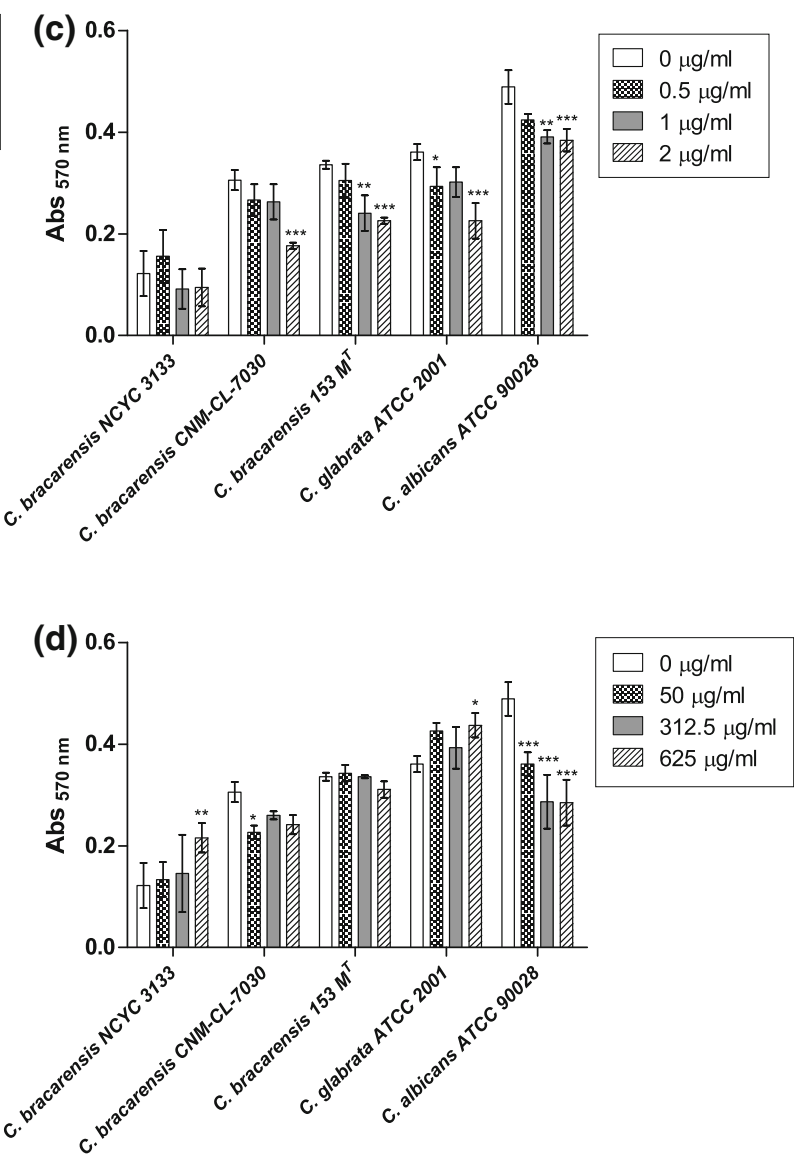

standard deviation, as result of four independent assays, where each condition was analyzed in triplicate. Statistical difference compared to respective control $(* p<0.05 ; * * p<0.01$; $* * * p<0.001)$

strains, specifically in terms of carbohydrates quantities. In fact, $C$. glabrata presented the highest values of carbohydrates comparatively to other strains under study. These results are in concordance with those revealed by several authors $[8,21]$, who showed that ECM of $C$. albicans biofilm contains a high level of carbohydrates and a low level of proteins and that biofilm matrices of $C$. glabrata are composed by high quantities of carbohydrates and proteins.

Among the several virulence factors, the ability to secrete hydrolytic enzymes has already been described for several Candida species, but not for C. bracarensis [18, 24-26]. Those compounds play a major role in the pathogenicity of these microorganisms since they are responsible for host tissue destruction [5]. The present work revealed that at least one strain of $C$. bracarensis 
(NCYC 3133) was able to secrete proteases, like $C$. tropicalis and C. albicans. Negri et al. [24] demonstrated proteolytic activity in some $C$. tropicalis clinical isolates from hospitalized patients, and Kumar et al. [25] detected that $83.6 \%$ of C. albicans isolates obtained from immunocompromised patients were capable to produce proteases. Moreover, concerning phospholipase activity, none of the strains of $C$. bracarensis produced extracellular phospholipases, like $C$. glabrata, but unlike $C$. albicans. On the contrary, all strains of $C$. bracarensis expressed total hemolytic activity, like the other species [18, 24, 26].

Concerning the antifungal agents' effect, $C$. bracarensis strains presented different susceptibility to amphotericin B and fluconazole, in planktonic lifestyle (Table 2). The present work showed that all C. bracarensis strains presented different MICs values for amphotericin B, with C. bracarensis NCYC 3133 being the most resistant strain even comparatively to C. albicans and C. glabrata. The results obtained for C. bracarensis $153 \mathrm{M}^{\mathrm{T}}$ are similar to those reported by Bishop et al. [27]. Unlike to what was observed for amphotericin B, the planktonic cells of the three $C$. bracarensis strains showed a similar behavior in the presence of fluconazole (Table 2). All strains could be classified as susceptible-dose-dependent, which allows the confirmation that these strains had not yet developed intrinsic resistance to this azole. Furthermore, in a previous study developed by Bishop et al. [27], C. bracarensis $153 \mathrm{M}^{\mathrm{T}}$ (also designated as $C$. bracarensis $\mathrm{TS}$ ) presented a fluconazole MIC value of $8 \mu \mathrm{g} / \mathrm{ml}$, slightly lower than the one obtained in this work. Moreover, the planktonic cells of $C$. bracarensis presented higher susceptible to fluconazole than the $C$. albicans and $C$. glabrata strains assayed. In opposition to what was expected, the susceptibility presented by C. bracarensis contrasted with the well-known resistance of $C$. glabrata to fluconazole [28, 29].

As it is known, Candida biofilms are generally 10-1000 times more resistant to antifungal agents than planktonic cells [22]. Nevertheless, in relation to $C$. bracarensis biofilms, there is still no investigation and, subsequently, there is a lack of information about the effect of amphotericin B and fluconazole against biofilm formation. Thus, after checking that $C$. bracarensis strains were able to form biofilms, the effect of amphotericin B and fluconazole on biofilm formation and pre-formed biofilms was assessed (Figs. 2, 3). Likewise to what was described for all
Candida species biofilms, C. bracarensis biofilm (Figs. 2, 3) presented also higher resistance comparatively to its planktonic counterparts (Table 2). In addition, it was verified that the antifungal effect was lower in the pre-formed biofilms (Fig. 3) than during biofilm formation (Fig. 2), regardless the agent tested. In fact, as it has been described, the antifungal resistance of Candida species biofilms increases with the complexity of biofilm structure [30]. The development of complex architectures restricts the penetration of drugs through the ECM, also hampering the access of these agents to cells present in the deep layers of the biofilm [22, 31]. During C. bracarensis biofilms' formation in the presence of amphotericin $\mathrm{B}$ (Fig. 2a, c), the biofilm of strain NCYC 3133 presented the lowest susceptibility, while the $C$. bracarensis $153 \mathrm{M}^{\mathrm{T}}$ biofilms was the most susceptible. These observations are in agreement with the results obtained for $C$. bracarensis planktonic cells susceptibility to amphotericin B (Table 2). Moreover, the biofilm of the $C$. bracarensis strains presented a similar susceptibility to $C$. glabrata, concerning amphotericin B. Candida bracarensis was also more susceptible than C. albicans strain accessed under this work. Fluconazole was also able to interfere in the biofilm formation of all $C$. bracarensis strains (Fig. 2b, d). Furthermore, the effect of this azole against $C$. bracarensis biofilm formation was higher than the observed for biofilms of $C$. glabrata and $C$. albicans. These findings are in accordance with what was observed for susceptibility of the planktonic cells to fluconazole (Table 2).

In the pre-formed biofilms (Fig. 3b, d), the strains NCYC 3133 and $153 \mathrm{M}^{\mathrm{T}}$ presented less susceptibility to fluconazole, among the $C$. bracarensis strains. Comparatively to other Candida species, the biofilm of C. bracarensis CNM-CL-7030 and C. albicans was the most susceptible to fluconazole in terms of the number of viable cells and values of total biomass, respectively. In the other hand, fluconazole presented the lower effect against pre-formed biofilms of $C$. bracarensis NCYC 3133 and C. glabrata, with a significant increase in the total biomass values, when in the presence of $625 \mu \mathrm{g} / \mathrm{ml}$. This observation contradicts the high susceptibility demonstrated by planktonic cells of C. bracarensis NCYC 3133 to fluconazole (Table 2).

The increase in total biomass values, observed in the biofilms of $C$. bracarensis NCYC 3133 and $C$. 
glabrata, clearly indicates the presence of biofilm resistance mechanisms to fluconazole. Although these mechanisms are not fully understood, there is a consensus in relation to some of them, specifically in the case of $C$. albicans biofilm [5]. One of them is the overexpression of drug target [32] and the presence of persister cells [33]. Another important factor involved in the antifungal resistance of biofilms is the physiological stress. This stress causes mutations in proteins that interfere in biofilm formation and, consequently, in its resistance [32]. ECM has been referred as an important mechanism also in the biofilm antifungal resistance because it functions as a protective barrier for the cells embedded in it, by hampering the diffusion of antifungal agents [32]. Nevertheless, and through the results obtained for ECM composition of strains under study (Table 1), no correlation was found between the matrix composition and the biofilm antifungal resistance, with exception of $C$. glabrata.

In conclusion, this study highlighted the differences between the $C$. bracarensis strains and the $C$. glabrata (or C. albicans), in terms of some virulence attributes and antifungal resistance. Specifically it was demonstrated, for the first time, that $C$. bracarensis strains tested are able to form biofilms, which are constituted by proteins and carbohydrates in their ECM. Moreover, it is important to highlight that $C$. bracarensis strains have proteinase and hemolytic activity and are unable to produce phospholipase and filamentous forms. Moreover, although the majority of the planktonic strains presented susceptibility to both amphotericin B and fluconazole, their biofilms appear much more resistant to these antifungals, similarly to other Candida species.

Despite being a rare species, due to the propensity of the isolates of $C$. bracarensis to display antifungal resistance and virulence attributes, the monitorization of these emerging pathogens is recommended. Concerning its identification, the use of standard chemotaxonomic methods by PCR fingerprinting with primer T3B [7] coupled with single or multiplex PCR are suggested [34].

Acknowledgments This work was supported by the projects PTDC/SAU-MIC/119069/2010, PEst-OE/EQB/LA0023/2013, from Fundação para a Ciência e Tecnologia (FCT), Portugal and "BioHealth—Biotechnology and Bioengineering approaches to improve health quality", Ref. NORTE-07-0124FEDER-000027, co-funded by the Programa Operacional Regional do Norte (ON.2 - O Novo Norte), QREN, FEDER.
The authors also acknowledge the project "Consolidating Research Expertise and Resources on Cellular and Molecular Biotechnology at CEB/IBB", Ref. FCOMP-01-0124-FEDER027462 .

\section{References}

1. Haynes K. Virulence in Candida species. Trends Microbiol. 2001;9(12):591-6. doi:10.1016/S0966-842X(01)02237-5.

2. Samaranayake YH, Samaranayake LP. Experimental oral candidiasis in animal models. Clin Microbiol Rev. 2001;14(2):398-429.

3. Pfaller MA, Diekema DJ, Jones RN, Sader HS, Fluit AC, Hollis RJ, et al. International surveillance of bloodstream infections due to Candida species: frequency of occurrence and in vitro susceptibilities to fluconazole, ravuconazole, and voriconazole of isolates collected from 1997 through 1999 in the SENTRY antimicrobial surveillance program. J Clin Microbiol. 2001;39(9):3254-9. doi:10.1128/jcm.39. 9.3254-3259.2001.

4. Warren TA, McTaggart L, Richardson SE, Zhang SX. Candida bracarensis bloodstream infection in an immunocompromised patient. J Clin Microbiol. 2010;48(12): 4677-9.

5. Silva S, Negri M, Henriques M, Oliveira R, Williams DW, Azeredo J. Candida glabrata, Candida parapsilosis and Candida tropicalis: biology, epidemiology, pathogenicity and antifungal resistance. FEMS Microbiol Rev. 2012;36(2): 288-305. doi:10.1111/j.1574-6976.2011.00278.x.

6. Johnson E. Rare and emerging Candida species. Curr Fungal Infect Rep. 2009;3(3):152-9. doi:10.1007/s12281009-0020-z.

7. Correia A, Sampaio P, James S, Pais C. Candida bracarensis sp. nov, a novel anamorphic yeast species phenotypically similar to Candida glabrata. Int J Syst Evol Microbiol. 2006;56(1):313-7.

8. Al-Fattani MA, Douglas LJ. Biofilm matrix of Candida albicans and Candida tropicalis: chemical composition and role in drug resistance. J Med Microbiol. 2006;55(8): 999-1008.

9. Kanafani ZA, Perfect JR. Resistance to antifungal agents: mechanisms and clinical impact. Clin Infect Dis. 2008;46(1):120-8.

10. Cowen LE. The evolution of fungal drug resistance: modulating the trajectory from genotype to phenotype. Nat Rev Microbiol. 2008;6(3):187-98.

11. Andersson DI, Hughes D. Antibiotic resistance and its cost: is it possible to reverse resistance? Nat Rev Microbiol. 2010;8(4):260-71.

12. Lockhart SR, Messer SA, Gherna M, Bishop JA, Merz WG, Pfaller MA, et al. Identification of Candida nivariensis and Candida bracarensis in a large global collection of Candida glabrata isolates: comparison to the literature. J Clin Microbiol. 2009;47(4):1216-7.

13. Silva S, Negri M, Henriques M, Oliveira R, Williams D, Azeredo J. Silicone colonization by non-Candida albicans Candida species in the presence of urine. J Med Microbiol. 2010;59(7):747-54. doi:10.1099/jmm.0.017517-0. 
14. Peeters E, Nelis HJ, Coenye T. Comparison of multiple methods for quantification of microbial biofilms grown in microtiter plates. J Microbiol Methods. 2008;72(2):157-65. doi:10.1016/j.mimet.2007.11.010.

15. DuBois M, Gilles KA, Hamilton JK, Rebers PA, Smith F. Colorimetric method for determination of sugars and related substances. Anal Chem. 1956;28(3):350-6. doi:10.1021/ ac60111a017.

16. Rüchel R. Proteinases of pathogenic fungi. Mycoses. 1999;42:48-52.

17. Price MF, Wilkinson ID, Gentry LO. Plate method for detection of phospholipase activity in Candida albicans. Med Mycol. 1982;20(1):7-14. doi:10.1080/00362178285 380031.

18. Negri M, Lorenço T, Silva S, Henriques M, Azeredo J, Oliveira R, editors. Effect of antifungal agents on nonCandida albicans Candida species enzymatic activity. Science and Technology Against Microbial Pathogens: Research, Development and Evaluation, Proceedings of the International Conference on Antimicrobial Research; 2011 3-5 November 2010; Valladolid: World Scientific Publishing Company.

19. Samaranayake YH, Dassanayake RS, Jayatilake JA, Cheung BP, Yau JY, Yeung KW, et al. Phospholipase B enzyme expression is not associated with other virulence attributes in Candida albicans isolates from patients with human immunodeficiency virus infection. J Med Microbiol. 2005;54(6):583-93. doi:10.1099/jmm.0.45762-0.

20. Luo G, Samaranayake LP, Yau JY. Candida species exhibit differential in vitro hemolytic activities. J Clin Microbiol. 2001;39(8):2971-4. doi:10.1128/jcm.39.8.2971-2974.2001.

21. Silva S, Henriques M, Martins A, Oliveira R, Williams D, Azeredo J. Biofilms of non-Candida albicans Candida species: quantification, structure and matrix composition. Med Mycol. 2009;47(7):681-9. doi:10.3109/1369378080 2549594.

22. Douglas LJ. Candida biofilms and their role in infection. Trends Microbiol. 2003;11(1):30-6.

23. Silva S, Negri M, Henriques M, Oliveira R, Williams DW, Azeredo J. Adherence and biofilm formation of non-Candida albicans Candida species. Trends Microbiol. 2011;19(5):241-7. doi:10.1016/j.tim.2011.02.003.

24. Negri M, Martins M, Henriques M, Svidzinski TE, Azeredo J, Oliveira R. Examination of potential virulence factors of
Candida tropicalis clinical isolates from hospitalized patients. Mycopathologia. 2010;169(3):175-82. doi:10. 1007/s11046-009-9246-0.

25. Kumar CP, Kumar SS, Menon T. Phospholipase and proteinase activities of clinical isolates of Candida from immunocompromised patients. Mycopathologia. 2006; 161(4):213-8. doi:10.1007/s11046-005-0157-4.

26. Kumar VG, Latha R, Vedhagiri K, Sathiamoorthi T, Jayarani G, Sasikala R, et al. Phospholipase C, proteinase and hemolytic activities of Candida spp. isolated from pulmonary tuberculosis patients. J Med Mycol. 2009; 19(1):3-10. doi:10.1016/j.mycmed.2008.11.002.

27. Bishop JA, Chase N, Magill SS, Kurtzman CP, Fiandaca MJ, Merz WG. Candida bracarensis detected among isolates of Candida glabrata by peptide nucleic acid fluorescence in situ hybridization: susceptibility data and documentation of presumed infection. J Clin Microbiol. 2008;46(2):443-6.

28. Abi-Said D, Anaissie E, Uzun O, Raad I, Pinzcowski H, Vartivarian S. The epidemiology of hematogenous candidiasis caused by different Candida species. Clin Infect Dis. 1997;24(6):1122-8.

29. Pfaller MA, Diekema DJ. Twelve years of fluconazole in clinical practice: global trends in species distribution and fluconazole susceptibility of bloodstream isolates of Candida. Clin Microbiol Infect. 2004;10(1):11-23.

30. Ramage G, Walle KV, Wickes BL, Lopez-Ribot JL. Characteristics of biofilm formation by Candida albicans. Rev Iberoam Micol. 2001;18(4):163-70.

31. Al-Fattani MA, Douglas LJ. Penetration of Candida biofilms by antifungal agents. Antimicrob Agents Chemother. 2004;48(9):3291-7.

32. Ramage G, Rajendran R, Sherry L, Williams C. Fungal biofilm resistance. Int J Microbiol. 2012;2012:1-14. doi:10. 1155/2012/528521.

33. Lewis K. Persister cells. Annu Rev Microbiol. 2010;64(1): 357-72. doi:10.1146/annurev.micro.112408.134306.

34. Neppelenbroek KH, Seó RS, Urban VW, Silva S, Dovigo LN, Jorge JH, Campanha NH. Identification of Candida species in the clinical laboratory: a review of conventional, commercial, and molecular techniques. Oral Dis. 2014;20: 324-44. 